Article

\title{
Evaluation of Cost Competitiveness of Electric Vehicles in Malaysia Using Life Cycle Cost Analysis Approach
}

\author{
Siti Indati Mustapa ${ }^{1, *(\mathbb{C})}$, Bamidele Victor Ayodele ${ }^{1, * \mathbb{C}}$, Waznatol Widad Mohamad Ishak ${ }^{1}$ and \\ Freida Ozavize Ayodele ${ }^{2}$ \\ 1 Institute of Energy Policy and Research, Universiti Tenaga Nasional, Jalan IKRAM-UNITEN, Kajang, \\ Selangor 43000, Malaysia; waznatol.widad@uniten.edu.my \\ 2 Department of Accounting and Finance, Faculty of Business, and Management, UCSI University, \\ Kuala Lumpur 56000, Malaysia; freida.ayodele@yahoo.ca \\ * Correspondence: indati@uniten.edu.my (S.I.M.); ayodelebv@gmail.com (B.V.A.)
}

Received: 4 May 2020; Accepted: 8 June 2020; Published: 30 June 2020

\begin{abstract}
The need to mitigate $\mathrm{CO}_{2}$ emissions from the transportation sector has necessitated the adoption of electric vehicles (EVs) and other forms of alternative vehicles. Despite the global rise of EVs demand as a complementary means of green transportations, the level of adoption in Malaysia is still not encouraging. Therefore, this study aimed to investigate the cost competitiveness of EVs in comparison with Hybrid Electric Vehicles (HEVs) and an Internal Combustion Vehicle (ICV) based on Malaysia scenarios. Using the existing data in Malaysia, life cost analysis (LCC) of two EVs was computed and compared with HEVs and ICVs. The study shows that Nissan leaf and BMW i3s EVs with LCC of $\$ 1.75$ and $\$ 2.5$ per km are not cost-competitive based on prevalent data available in Malaysia compared to the HEVs and ICV. Based on the sensitivity analysis, changes in the components of the operating costs significantly influence the accumulated cost of ownership of the EVs whereas the cost of ownership of the HEVs and ICVs did not experience any significant influence. The findings from this study could serve as bases for policymakers to formulate appropriate policies and strategies to improve the competitiveness of EVs in Malaysia.
\end{abstract}

Keywords: electric vehicles; electric vehicle policies; cost competitiveness; life cycle cost; Malaysia

\section{Introduction}

The transportation sector is one of the highest contributors to carbon dioxide $\left(\mathrm{CO}_{2}\right)$ emissions globally [1]. According to Khalili et al. [2], global transportation demands have significantly increased greenhouse gas emissions. The transportation sector was reported to have accounted for $19 \%$ of the global final energy demand in 2015 [2]. Hence, responsible for emissions of approximately $8260 \mathrm{MtCO}_{2}$ eq [2]. In view of these, electric vehicles (EVs) and other alternative vehicles have been projected to facilitate the mitigations of $\mathrm{CO}_{2}$ emissions [3,4]. Therefore, the demand for EVs has been on the increase since 2013 as shown in Figure 1. Similarly, since the economic activities in Malaysia has been mainly driven by energy derived from fossil fuel [5-7]. The transportation sector which is one of the key drivers of the economy mainly depends on fossil fuel for its activities [5]. Hence, the consumption of fossil fuel has continuously resulted in the emission of $\mathrm{CO}_{2}$ as shown in Figure 2. This phenomenon has earlier been analyzed by Mustapa and Bekhet [8] who reported that the transportation sector in Malaysia will continue to contribute to $\mathrm{CO}_{2}$ emissions unless certain policies are implemented by the government. The authors proposed that the removal of fuel subsidies can drastically reduce $\mathrm{CO}_{2}$ emissions in Malaysia. To combat $\mathrm{CO}_{2}$ emissions from the transportation sector, the government of Malaysia has 
formulated a series of policies in the last decade to encourage the use of alternative vehicles such as the battery electric vehicles (BEVs). One of such recent policy is the National Automotive Policy (2020) [9-11]. Based on the Malaysia government National Automotive Policy (2020), depicted in Figure 3, several technology developments project has been mapped out to improve the ease of owing EVs in Malaysia. These projects which have been estimated to cost RM 18.07 Million (US\$4.25 Million) include the development of advanced electrode and electrolytes for Lithium-ion Battery (LiB), Battery Charge, mechanical and thermal management system, Lithium ion Battery Module Packaging and Testing, Next-Generation Battery Technology Roadmap. In the past, the series of government policies have supported the growth of the BEVs market in Malaysia. It is anticipated by the government that there would be an increase in Malaysia's participation in the regional electric mobility after 2030. To achieve this target, impeding factors such as inadequate infrastructure to support EVs, high cost, and limited technological know-how must be addressed.

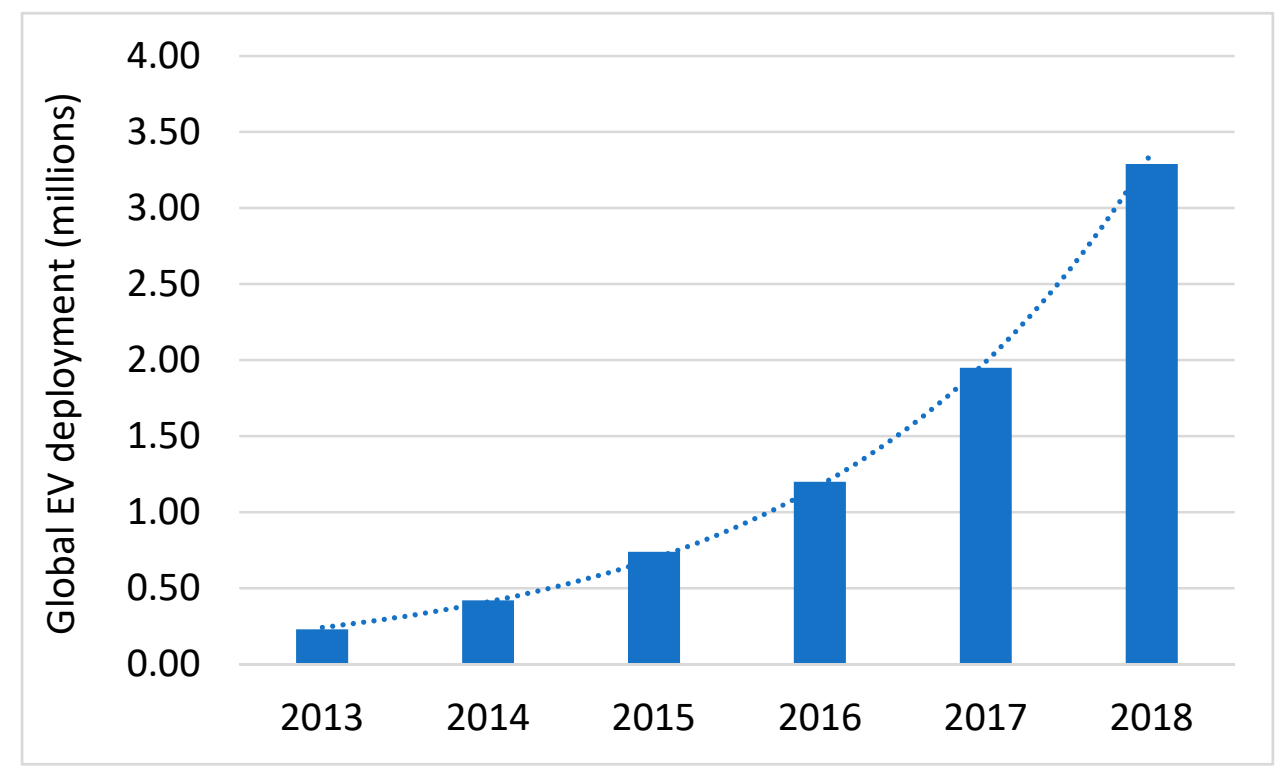

Figure 1. Global EV development from 2013 to 2018 [12].

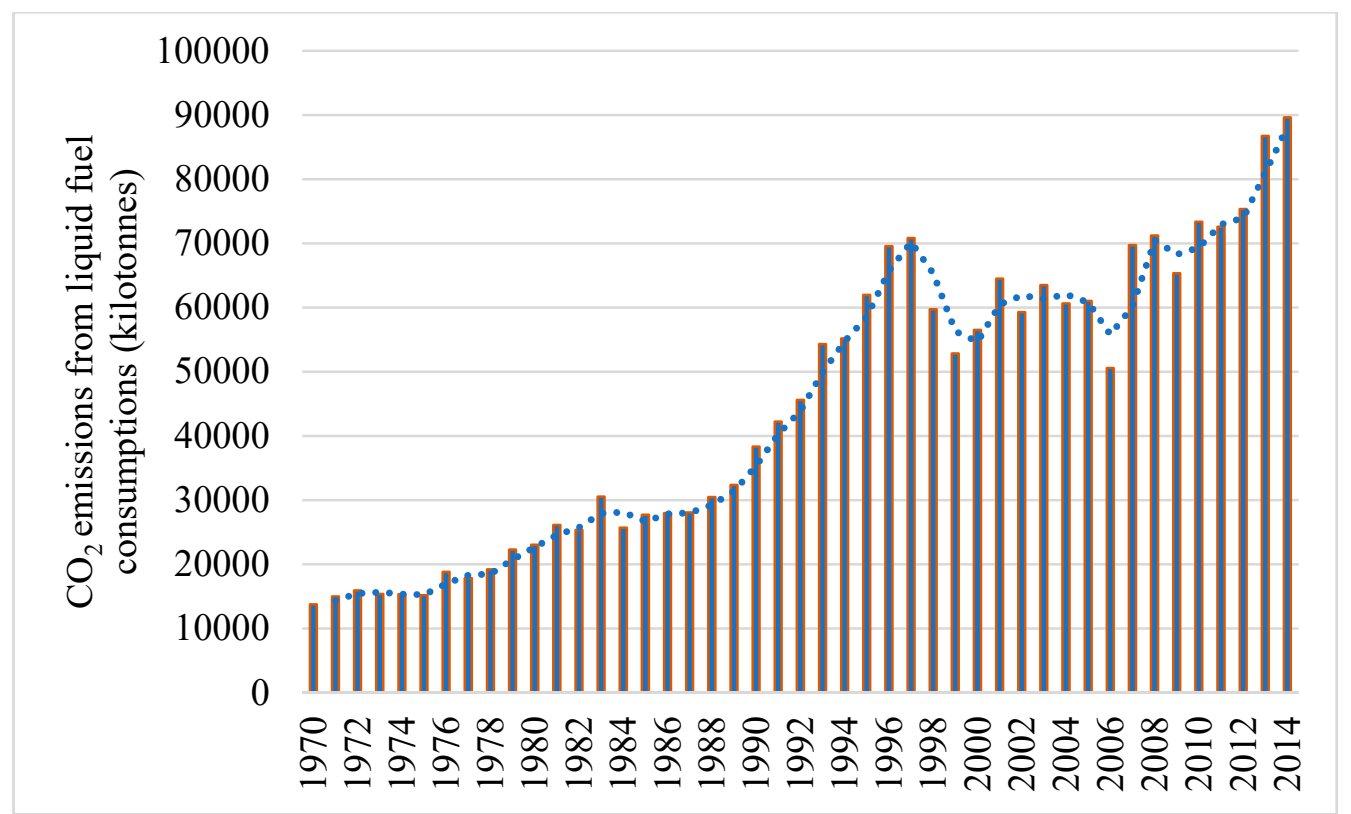

Figure 2. The trend of $\mathrm{CO}_{2}$ emissions from liquid fuel consumption in Malaysia [13]. 




Figure 3. EV component of the Malaysia National Automotive Policy (2020) [9].

On the international scene, a series of studies have been reported on the cost analysis of EVs in various countries. Lieven et al. [14] forecasted the market potential of EVs in Germany. The study which employed 14 categories of vehicles used four predictors namely priority of price, priority of range, price barrier, and range barrier for the forecasting. The study predicted $5 \%$ of potential buyers of EVs among the 14 categories of vehicles investigated. In a similar study, Mersky et al. [15] investigated the effectiveness of incentives on EVs in Norway. The authors analyzed the sales of EVs on a regional and municipal basis in Norway and found that accessibility to EV charging infrastructure had the most significant predictive power for EV sales growth. Vergis and Chen [16] performed a comparative analysis of plug-in EV adoption in the United States. The authors considered social, economic, geographic, and policy factors in the adoption of EV. The study revealed that the factors considered have a strong correlation with the EV markets. Wang et al. [17] performed a discrete cost analysis to determine the effectiveness of policy incentives EVs acceptance in China. Based on the discrete analysis, the probability of the EV acceptance improves provided there are policy incentives. In a similar study, Diao et al. [18] reported a life cycle private cost analysis of EVs in China based on the intangible cost of traffic policies. The findings showed that the EVs considered were not economically competitive compared with the ICVs based on the tangible costs of the vehicles. Kara et al. [19] investigated the life cycle cost analysis of EVs in Australia. The study shows that the 2011 Nissan leaf EV has a higher life cycle cost compared to the Toyota Corolla ICV.

Apart from the international scene, a series of studies related to EVs have also been reported in Malaysia. Adnan et al. [20] reported the significance of encouraging the adoption of EVs in Malaysia. The authors revealed that environmental concern was the main intention of EV adoption and other alternative vehicles in Malaysia. The author further substantiated the customers' purchase intention to adopt EVs using the extended theory of planned behavior [21]. Islam et al. [22], reported that the location of the charging infrastructure could also influence customers' perception towards the adoption of EV. Their study proposed optimum locations and sizing of a rapid charging station that could be beneficial to EV users. In line with the work of Adnan et al. [21], Salehen et al. [23] also reiterate that the development of an effective battery management system in Malaysia could boost the adoption of EV. Based on Sang et al. [24] model, the acceptance of EVs in Malaysia is dependent on factors such as social influences, performance attributes, financial benefits, environmental concerns, demographics, infrastructure readiness, and government intervention. In addition to all these factors, the cost competitiveness of EVs could also influence the customers' decision to adopt EVs in Malaysia. To date, the cost competitiveness of EVs in Malaysia has not been reported in the literature. According to Ayodele et al. [25], life cycle cost analysis is a robust approach to investigate the cost competitiveness of EV. Therefore, the main objective of this study is to employ the technique of life cycle cost analysis to investigate the cost competitiveness of EVs in Malaysia. 


\section{An Overview of Various Approaches to Life Cycle Cost Analysis}

Life cycle cost analysis offers the platform for estimating the total costs associated with a product as a function of its development, production, utilization, and disposal. Various approached for performing life cycle cost analysis have been developed and utilized in literature [25]. These approaches can generally be categorized as conceptual, analytical, and heuristic [26]. The conceptual approach of life cycle cost analysis entails the use of hypothesized interaction to convey a qualitative framework. The conceptual approach has the benefit of being flexible and the tendency to be adapted to a great variety of systems. The life cycle cost analysis using the conceptual approach does not require many details for quantifying the cost features of any system. Unlike the conceptual approach, the analytical approach for life cycle cost analysis involves the formulation of mathematical expression used for the description of a product based on a set of assumptions. While the Heuristic approach for life cycle cost analysis enables an ample solution to be provided without a guarantee of the optimum solution. Table 1 summarizes the various literature on the life cycle assessment of EVs and other types of alternative vehicles. Delucchi et al. [27] developed an integrated model for the life cost analysis of EV. The integrated model was employed to analyze the performance, energy use, manufacturing cost, retail cost, and the life cycle costs of EVs. The model employed consists of a sub-model of vehicle cost and weight, a sub-model of vehicle energy use, and the assessment of the periodic ownership and operating cost. Based on the life cycle cost analysis, the authors revealed that a cost-competitive EVs can be obtained if a lower manufacturing cost and longer battery life can be attained. Unlike Delucchi et al. [27], Ogden et al. [28] performed a comparative societal life cycle cost analyses of various hybrid vehicles and EVs. The life cycle cost was expressed as a summation of the vehicle's first cost of purchase and the present value of the lifetime cost of various components. The various components consist of the cost of fueling, non-fuel operation and maintenance, full fuel cycle air-pollutant damages, full fuel cycle greenhouse gas emissions damages, and oil supply insecurity. The study revealed that advanced hybrid vehicles have a lower life cycle cost than the ICVs. Lipman and Dulucchi [29] employed ADVISOR HEV performance model for life cycle cost analysis of the hybrid gasoline-electric vehicle. The LCC analysis was performed incorporating the EV capital cost, battery, tray, and auxiliary costs, insurance cost, cost of battery charging, maintenance and repairs costs, engine oil cost, tire replacement costs, parking, tolls, fines and accessories cost, registration cost, vehicle safety, and emissions inspection cost, federal, state, and local taxes. The study shows that the hybridization of the vehicle helps to reduce its life cycle cost. The authors reported that the design of the hybrid EV makes it more economical considering the first cost and the levelized lifecycle cost compared to the design of the BEV. Hence, a more economical HEVs is realizable in terms of private ownership costs compared to the BEVs. A cost prediction model was employed by Offer et al. [30] as the life cycle cost analysis tool for BEVs, FCEVs, and FCHEVs. The cost model incorporated the capital cost of the various vehicles, the running costs, and the end-of-life cost. The life cycle cost of BEVs and FCHEV was found to be lower than FCEVs. Based on the cost prediction model, the life cycle costs of the FCHEV and the BEV were projected to be competitive with the ICEV by 2030. The cost predictions were found to be sensitive to capital costs and the hydrogen cost. Sharma et al. [31] estimated the total cost of vehicle ownership of ICVs, HEVs, and EVs based on Australia driving conditions. The total cost of ownership of the various vehicles was calculated as the summation of the purchasing cost plus the operating cost minus the cost of re-sale of the vehicles. The results showed that the total cost of ownership of the hybrid and EVs are lower compared to that of ICVs. However, the LCC of the hybrid EVs were found to be slightly lower than the EVs. The LCC was found to be significantly influenced by the capital and running costs throughout the ownership period. 
Table 1. Summary of selected literature on life cycle cost analysis of EVs, and other alternative vehicles.

\begin{tabular}{|c|c|c|c|c|}
\hline System & Study Objective & LCC Methodology & Study Outcome & Reference \\
\hline BEVs & $\begin{array}{l}\text { To develop a model } \\
\text { for calculating life } \\
\text { cycle cost analysis } \\
\text { of EVs and ICVs }\end{array}$ & $\begin{array}{l}\text { An integrated } \\
\text { model }\end{array}$ & $\begin{array}{l}\text { The study revealed } \\
\text { that the EVs can be } \\
\text { cost-competitive } \\
\text { with ICVs if lower } \\
\text { manufacturing cost } \\
\text { and longer battery } \\
\text { life can be achieved }\end{array}$ & Delucchi et al. [27] \\
\hline $\begin{array}{l}\text { ICVs, and various } \\
\text { hybrid vehicles }\end{array}$ & $\begin{array}{l}\text { To compare the life } \\
\text { cycle cost analysis } \\
\text { of various } \\
\text { advanced hybrid } \\
\text { alternative vehicles } \\
\text { with standalone } \\
\text { ICVs }\end{array}$ & $\begin{array}{l}\text { The LCC was } \\
\text { estimated as the } \\
\text { sum of vehicle first } \\
\text { cost plus the } \\
\text { present value of } \\
\text { lifetime costs of the } \\
\text { various } \\
\text { components. }\end{array}$ & $\begin{array}{l}\text { The study revealed } \\
\text { that the various } \\
\text { advanced hybrid } \\
\text { vehicles have lower } \\
\text { lifecycle costs than } \\
\text { the ICVs. }\end{array}$ & Ogden et al. [28] \\
\hline $\mathrm{HEV}$ & $\begin{array}{l}\text { To analyze the life } \\
\text { cycle costs of } \\
\text { hybrid } \\
\text { gasoline-electric } \\
\text { vehicles. }\end{array}$ & $\begin{array}{l}\text { ADVISOR HEV } \\
\text { performance model }\end{array}$ & $\begin{array}{c}\text { Vehicle } \\
\text { hybridization } \\
\text { produced the least } \\
\text { life cycle costs close } \\
\text { to the baseline } \\
\text { vehicles. }\end{array}$ & $\begin{array}{l}\text { Lipman and } \\
\text { Delucchi [29] }\end{array}$ \\
\hline $\begin{array}{l}\text { BEVs, FCEVs, } \\
\text { FCHEVs }\end{array}$ & $\begin{array}{l}\text { To compare the life } \\
\text { cycle cost analysis } \\
\text { of BEVs, FCEVs, } \\
\text { and FCHEVs. }\end{array}$ & $\begin{array}{l}\text { Cost prediction } \\
\text { analysis }\end{array}$ & $\begin{array}{l}\text { The life cycle cost } \\
\text { of BEVs and } \\
\text { FCHEV was found } \\
\text { to be lower } \\
\text { than FCEVs. }\end{array}$ & Offer et al. [30] \\
\hline $\begin{array}{l}\text { ICVs, HEVs, } \\
\text { and EVs }\end{array}$ & $\begin{array}{l}\text { To estimate the } \\
\text { total cost of vehicle } \\
\text { ownership of ICVs, } \\
\text { HEVs, and EVs }\end{array}$ & $\begin{array}{l}\text { The total cost of } \\
\text { ownership was } \\
\text { calculated as } \\
\text { purchase price }+ \\
\text { operating cost } \\
\text {-Resale value }\end{array}$ & $\begin{array}{l}\text { The total cost of } \\
\text { ownership of the } \\
\text { hybrid and EVs are } \\
\text { lower compared to } \\
\text { that of ICVs. }\end{array}$ & Sharma et al. [31] \\
\hline
\end{tabular}

\section{Material and Methods}

The life cycle cost analyses employed by Kara et al. [19] and Delucchi et al. [27] were adopted in this study due to its simplicity and absence of complicated assumptions. As depicted in Figure 4, there are three components of the life cycle cost analysis namely the purchase price or the manufacturer's suggested retail price (MSRP), the operating costs, and the cost of disposal (or resale value). All these components can be categorized under three sub-headings namely the acquisition phase, the operation phase, and the disposal phase. As shown in Figure 1, the MSRP is the recommended price by the manufacturer of the product to the retailer. The operating cost includes the cost of fuel, electricity, servicing, and registration. The resale cost is estimated based on the depreciation of the car for a period of 20 years. Series of assumptions were made in the calculation of the life cycle cost analysis which include: The cost of maintenance and repair which exclude cleaning and towing; cost of periodic purchase of engine oil; cost of replacement of tires; cost of parking, tolls and other accessories; cost of registration; various categories of taxes; inspection fees. A functional unit of $1 \mathrm{~km}$ driven by the EVs in Peninsular Malaysia was assumed. The EVs useful life was assumed to be 20 years with an annual mileage of $28,188 \mathrm{~km}$. The local currency (Malaysia Ringgit (RM)) was converted to USD at the prevailing exchange rate while carrying out this study. The details specifications of the various vehicles used for this study are summarized in Table 2 More details are provided in Table S1. The models of the EVs include 2019 Nissan Leaf EV, and 2019 BMW i3s. For comparison two models of hybrid cars namely 2018 Hyundai Ioniq HEV Plus and 2018 Jazz 1.5 Hybrid were adopted. The ICV used 
for comparison is Perodua Myvi 1.5 High AT. The details of the MSRP for each of the vehicles are summarized in Table 2.

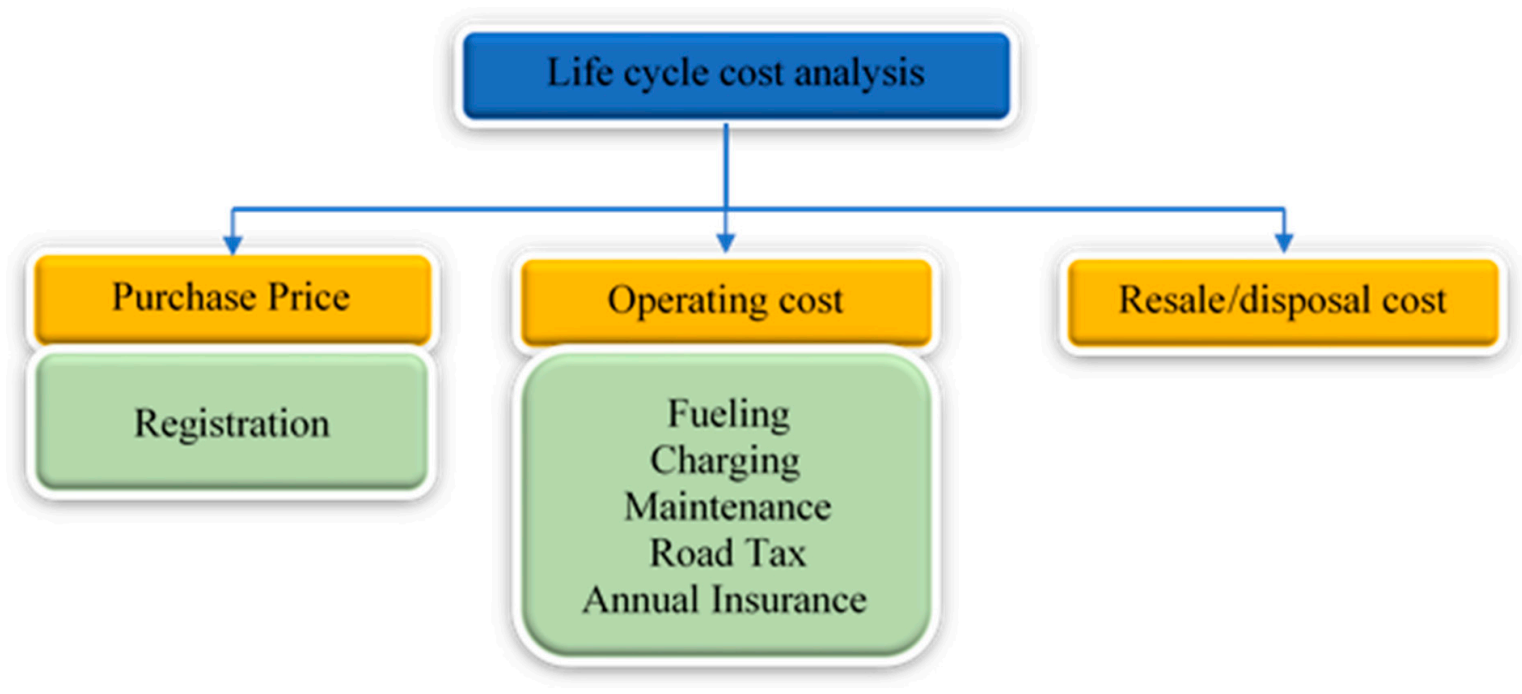

Figure 4. Schematic representation of the life cycle cost approach.

Table 2. Details of the various vehicles used for the study.

\begin{tabular}{cccccccc}
\hline $\begin{array}{c}\text { Brand } \\
\text { Name }\end{array}$ & Year & Model & Type & MSRP (\$) & Range & $\begin{array}{c}\text { Battery } \\
\text { Size }\end{array}$ & $\begin{array}{c}\text { Battery } \\
\text { Life }\end{array}$ \\
\hline Nissan & 2019 & Leaf EV & EV & $44,444.24$ & 270 & 40 & 6 \\
BMW & 2019 & BMW i3s & EV & $65,647.06$ & 260 & 42 & 6 \\
Hyundai & 2018 & Ioniq HEV Plus & HEV & $25,879.53$ & - & 1.56 & 8 \\
Honda & 2018 & Jazz 1.5 Hybrid & HEV & $18,844.94$ & 2 & 0.86 & 8 \\
Perodua & 2020 & Myvi 1.5 High AT & ICE & $11,832.94$ & - & - & - \\
\hline \multicolumn{3}{c}{ Source: [32]. }
\end{tabular}

\section{Results and Discussion}

The $\mathrm{CO}_{2}$ emissions from each of the categories of vehicles analyzed in this study are depicted in Figure 5. As shown in Figure 5, the EVs have a $\mathrm{CO}_{2}$ emission advantage compared to the hybrid and the ICV. Hawkins et al. [33] revealed that EVs-based $\mathrm{CO}_{2}$ emissions are depended on the sources of the electricity. Based on the outcome of their study, the EVs powered by the European electricity mix offer significant $\mathrm{CO}_{2}$ emissions compared to the convectional ICVs. Furthermore, Girardi et al. [34] established that the $\mathrm{CO}_{2}$ emissions by EVs are comparably low than that of ICVs based on Italy electricity mix scenarios. As established by Sang et al. [24], one of the major factors that influence customer awareness of EVs is environmental concerns.

The number of registered electric vehicles has been fluctuating over the years as shown in Figure 6. According to the Malaysia Automotive Association report, EV sales in 2018 accounted for only $2.2 \%$ of the total unit of cars sold which was far lower compared to what is obtained in other Asia countries. Several factors have been identified as reasons for the low patronage of EVs in the past years. Sang et al. [24] identified some of the factors affecting the acceptance of EVs in Malaysia as social influence, performance attributes, financial benefits, environment concerns, demographics, infrastructure readiness, and government intervention. This dearth of awareness had seriously hampered the growth of the EV market in Malaysia. Besides the dearth of awareness, one major concern that has been raised as a drawback is inadequate charging facilities. One major concern of the study is the cost competitiveness of the EVs in comparison to hybrid and ICVs which will be discussed in the subsequent section. 


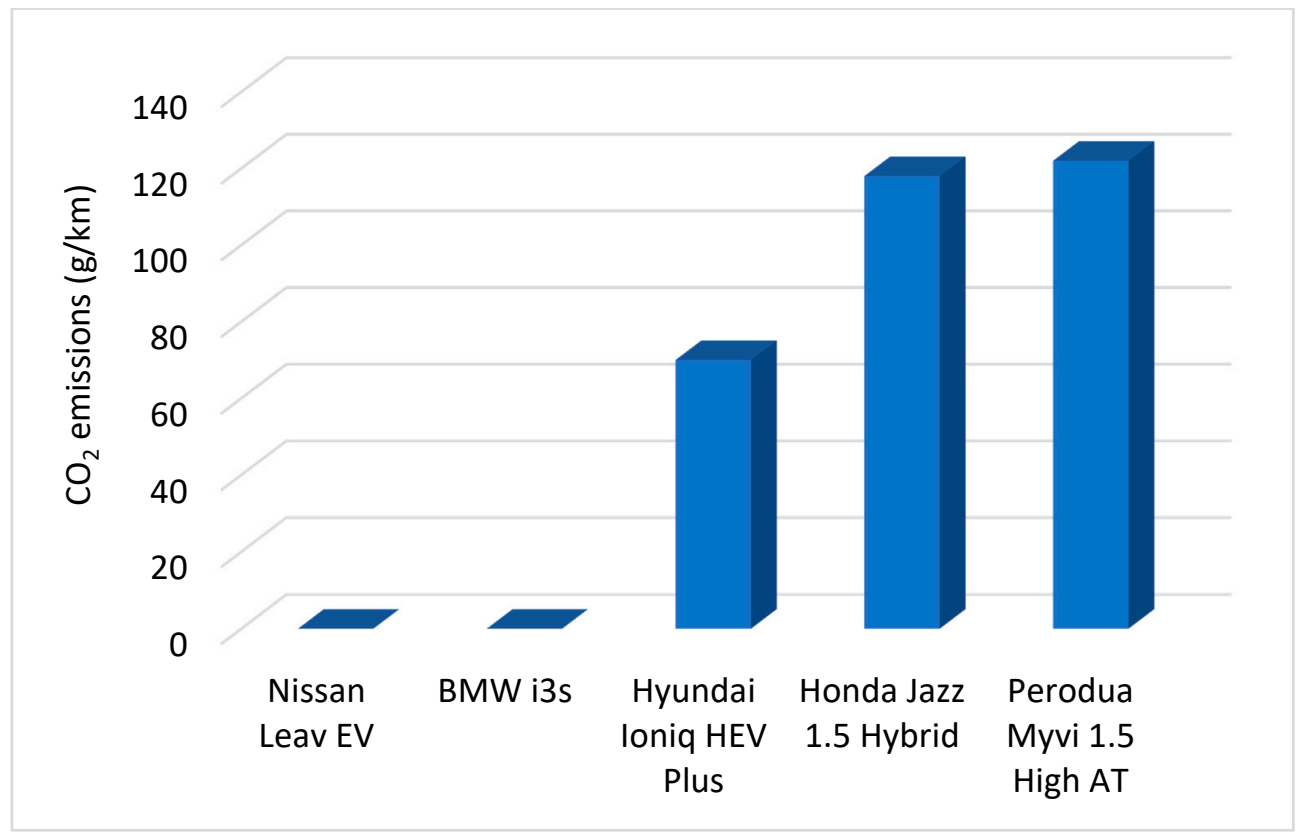

Figure 5. $\mathrm{CO}_{2}$ emissions from the various vehicle adopted in this study.



Figure 6. Number of registered electric vehicle in Malaysia from 2011 to 2018.

The manufacturing recommended sales price (MRSP) of each of the EVs in comparison with the hybrid and the ICV are depicted in Figure 7. The MSRP of the two models of the EVs is higher compared with the Hyundai Ioniq HEV plus, Honda jazz 1.5 hybrids, and Perodua Myvi1.5 High AT. Kara et al. (2017) reported that the MRSP in the acquisition phase of EVs significantly influences the life cycle cost. This was because the MRSP component of the acquisition was very high compared to other cost components in the operation and disposal stage. A comparison of the MRSP of EVs, ICVs, and FCEVs by also revealed that the MSRP of EV is higher compared to the other forms of vehicle. Several studies have revealed that MSRP of EVs is anticipated to continue to be higher than the ICVs and other forms of alternative vehicles. However, some authors are optimistic that the MSRP of EVs might drop drastically with advanced technology and cheaper materials for producing batteries, key 
policies, and market expansion. For instance, the cost of EVs in the US was reported to drop by $13.4 \%$ from 2018 to 2019 [35]. Gent (2019) opined that EVs projected to be cheaper than the conventional ICVs by 2022 based on the rapidly falling price of lithium-ion batteries which accounted for the larger part of the total production cost. According to Gent, in the last ten years, the lithium-ion batteries cost accounted for half of the total cost of the EVs but has drastically dropped to $33 \%$ presently and is projected to further drop to $20 \%$ of the total cost by 2025 [36].



Figure 7. The MSRP of the EVs in comparison with the hybrid and ICVs.

The operating costs of the EVs in comparison with the HEVs and ICV are depicted in Figure 8. Two different scenarios were employed for calculating the operating costs for the HEVs and the ICV. The scenarios include the usage of regular petrol fuel (RON 95) and the premium petrol fuel (RON 97). Based on the analysis, the operating costs of the Nissan leaf EV, BMW i3s, Hyundai Ioniq HEV Plus, Honda Jazz 1.5 HEV, and Perodua Myvi 1.5 High AT are $\$ 0.083, \$ 0.087, \$ 0.045, \$ 0.017$, and $\$ 0.023$ per $\mathrm{km}$ respectively using regular petrol fuel. Similarly, based on the usage of the premium petrol fuel, the operating cost of the Hyundai Ioniq HEV Plus, Honda Jazz $1.5 \mathrm{HEV}$, and Perodua Myvi 1.5 AT are $\$ 0.065, \$ 0.058$, and $\$ 0.055$, respectively while that of the EVs remain unchanged. It can be seen that the operating costs of the two EVs are lower compared to the Hyundai Ioniq HEV Plus, Honda Jazz 1.5 HEV, and Perodua Myvi 1.5 AT. This can be attributed to the fact that the cost of maintenance of the two EVs is lower compared to the two HEVs and the ICV. A similar trend has been reported by Diao et al. [18], who investigated the cost competitiveness of EVs in China using the LCC approach. The study revealed that the maintenance cost of the BEVs was lower compared to the ICVs with or without subsidy. One of the major contributors to the maintenance cost of the EVs is the cost of charging the batteries. Hence, a 5\% annual increment on the costs incurred for charging the battery for the whole period of ownership was employed for sensitivity analysis shown in Figure 9. Interestingly, the $5 \%$ annual increment on the cost of charging did not have much influence on the operating cost of the Hyundai Ioniq HEV Plus throughout ownership. However, there was a slight influence on the operating costs of the Nissan leaf EV, Jazz 1.5 Hybrid and the BMW i3s during the period of ownership based on the $5 \%$ annual increase on the cost of charging. While a sharp increase in the operating cost of the Honda jazz 1.5 HEV was observed based on the 5\% increase in the cost of charging during the period of ownership. The adequate knowledge of the impact of changes in the key components 
of the operating cost (for instance, the cost of charging the EV) will help various stakeholders and policymakers in formulating policies that will improve the adoption of EVs in Malaysia.



Figure 8. Operating cost of the various vehicles ( ${ }^{*}$ Cost based on regular petrol price ${ }^{* *}$ Cost based on premium petrol price).

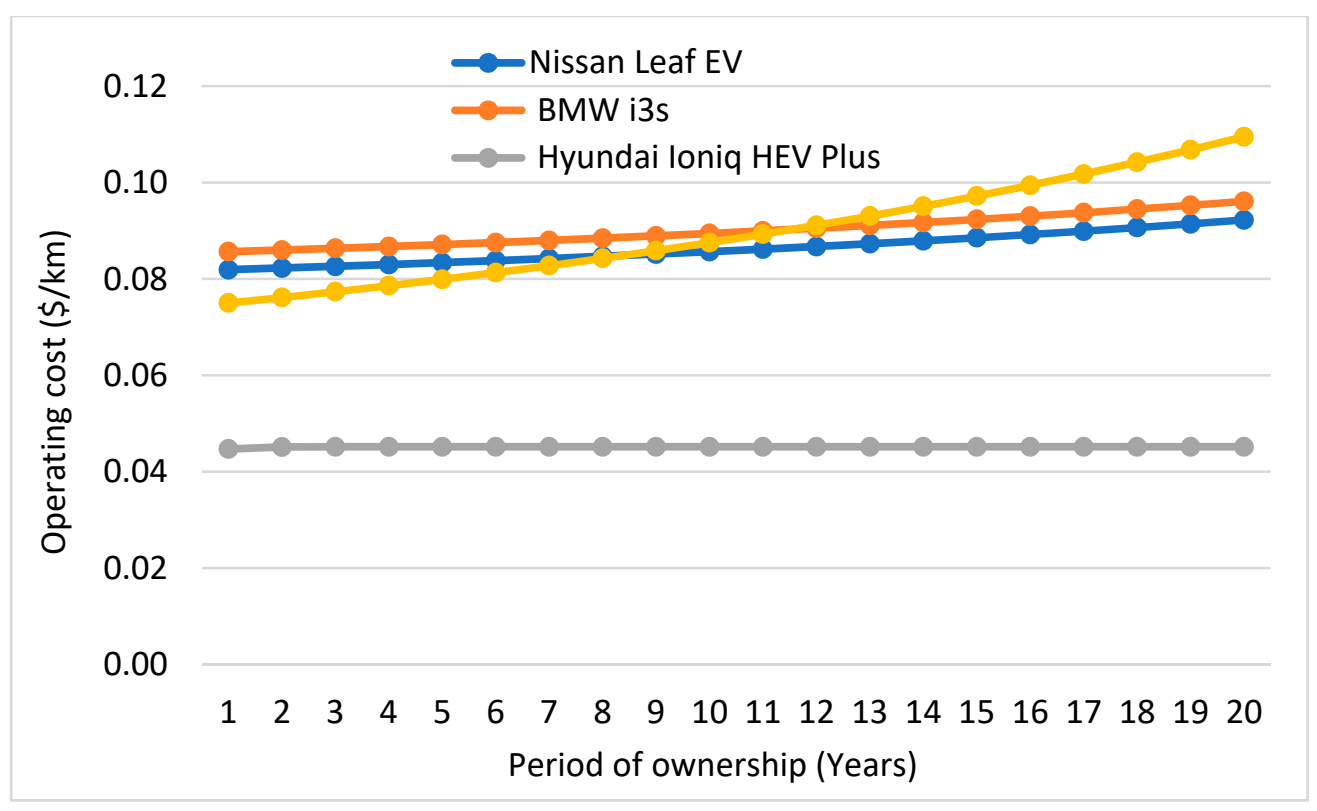

Figure 9. Sensitivity analysis on the operating costs of the EVs and HEVs based on $5 \%$ annual increment of battery cost.

The total LCC per km of EVs, HEVs, and the ICV is depicted in Figure 10. The analysis shows that Nissan leaf EV, BMW i3s, Hyundai Ioniq HEV plus, Honda jazz 1.5 HEV, and Perodua Myvi 1.5 AT have LCC per km of 1.75, 2.5, 1.0, 0.71, and 0.52, respectively. The LCC per km of the EVs are higher compare with the HEVs and the ICV. This implies that the cost of owing EVs in Malaysia is not competitive compare to the HEVs and the ICV. Nevertheless, the LCC per km obtained for the EVs in this study is comparatively lower compared with that obtained in by AECOM [37], Baker [38], 
EPRI [39], and Kara et al. [19] as shown in Figure 11. The sensitivity analysis of the EVs, HEVs, and the ICV based on the 5\% annual increase in the cost of charging the EV battery and using the regular petrol fuel is depicted in Figure 12. Interestingly, the accumulated cost of ownership of the HEVs and the ICV was not significantly influenced by the changes in the components of the operating costs based on the prevailing market scenarios in Malaysia. On the contrary, the accumulated cost of ownership of the EVs during the 20 years of the period was significantly influenced by the changes in the components of the operating cost. As indicated in this, the cost of ownership of EVs in Malaysia is not yet competitive. Hence, series of policies can be put in place to improve ease of adoption of EVs in Malaysia. The few patronages of EVs in Malaysia despite the high cost of ownership compared to the ICVs can be attributed to the inbuilt extra luxury features that make it attractive in addition to the environmental benefits. As reported by Hidrue et al. [40], there was an increase in the proportion of people willing to pay a premium as the attribute of EV improves.

Although the government has put forward series of schemes such as free charging for a minimum annual subscription, and reduction in road tax of the EVs, there is no policy in place to promote incentives for people to own an EV. Some schools of thought believe that the accumulated cost savings from the free charging, not buying fuel and the reduction in road taxes is significantly low compared to the cost differenced between conventional ICV and an equivalent EV. For the cost of owning EV in competitive in Malaysia, the government must take a leap from countries such as France, Germany, the UK, and the Netherland where the cost of ownership of EVs is lower compared to that of ICVs. This was made possible due to several government policies such as high cost of fuel as well as a tax break and heavily subsidized cost of purchase [41].

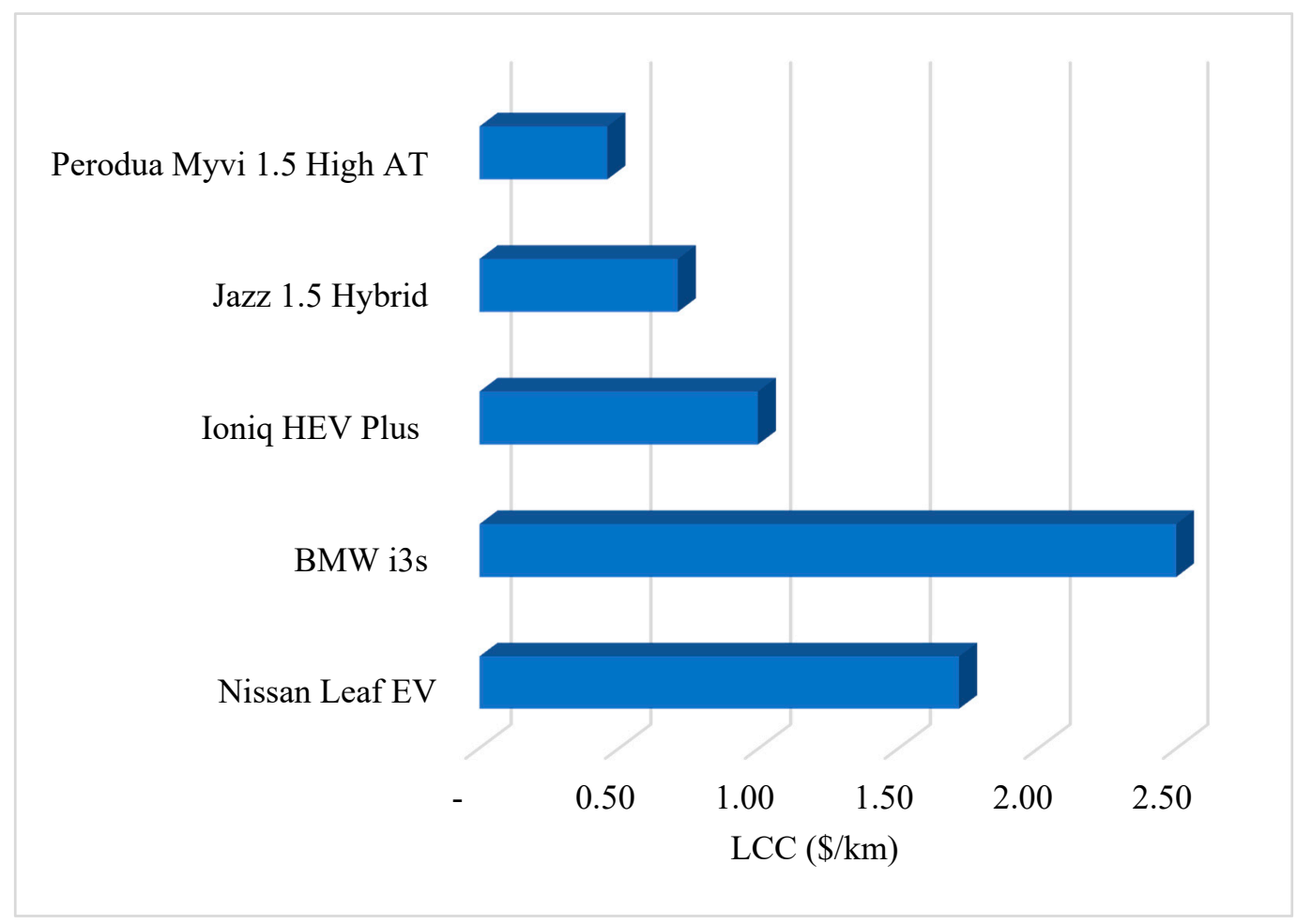

Figure 10. LCC of the EVs in comparison with hybrid and ICVs. 


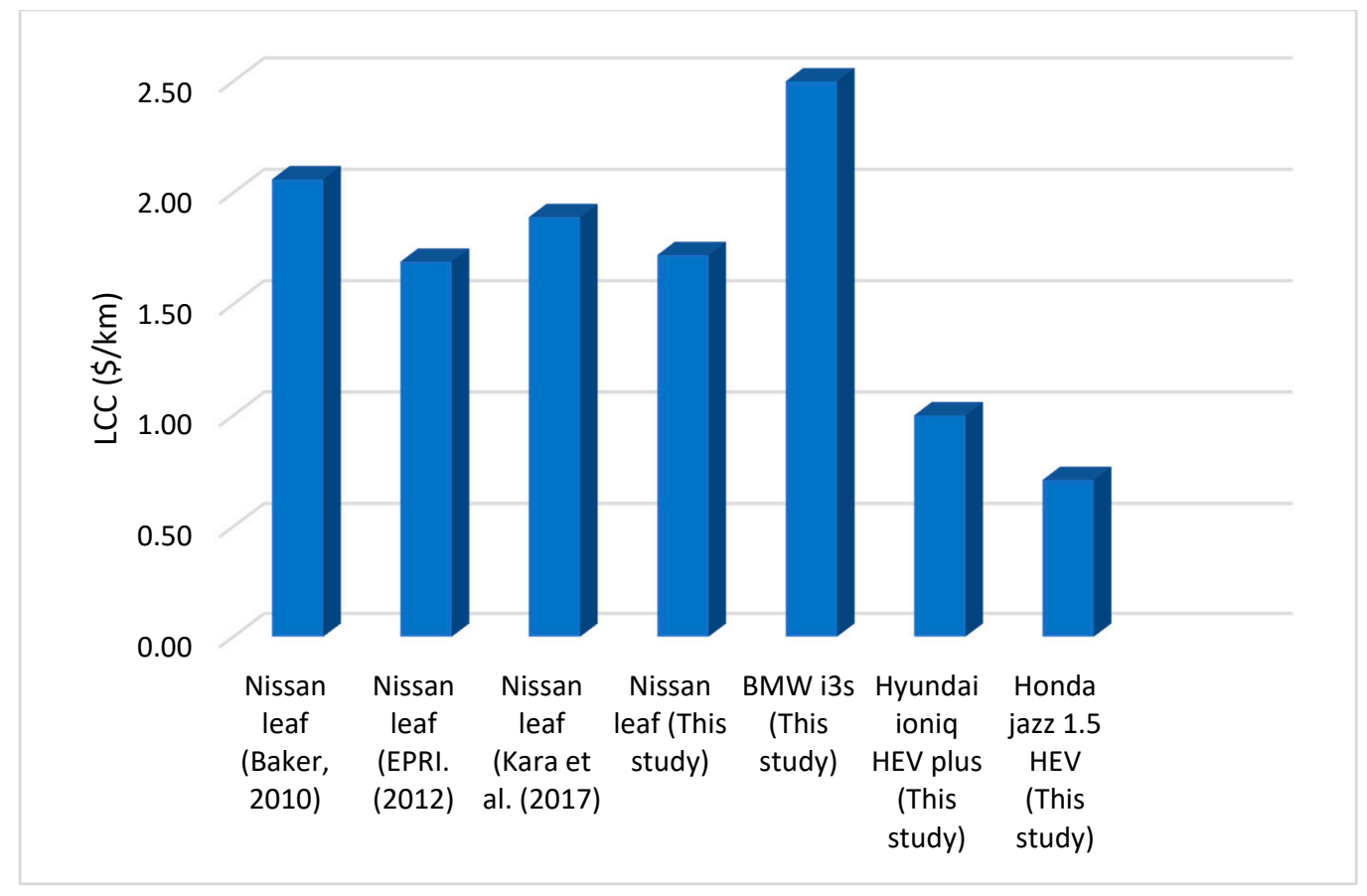

Figure 11. Comparison of the LCC of the EVs in this with literature.

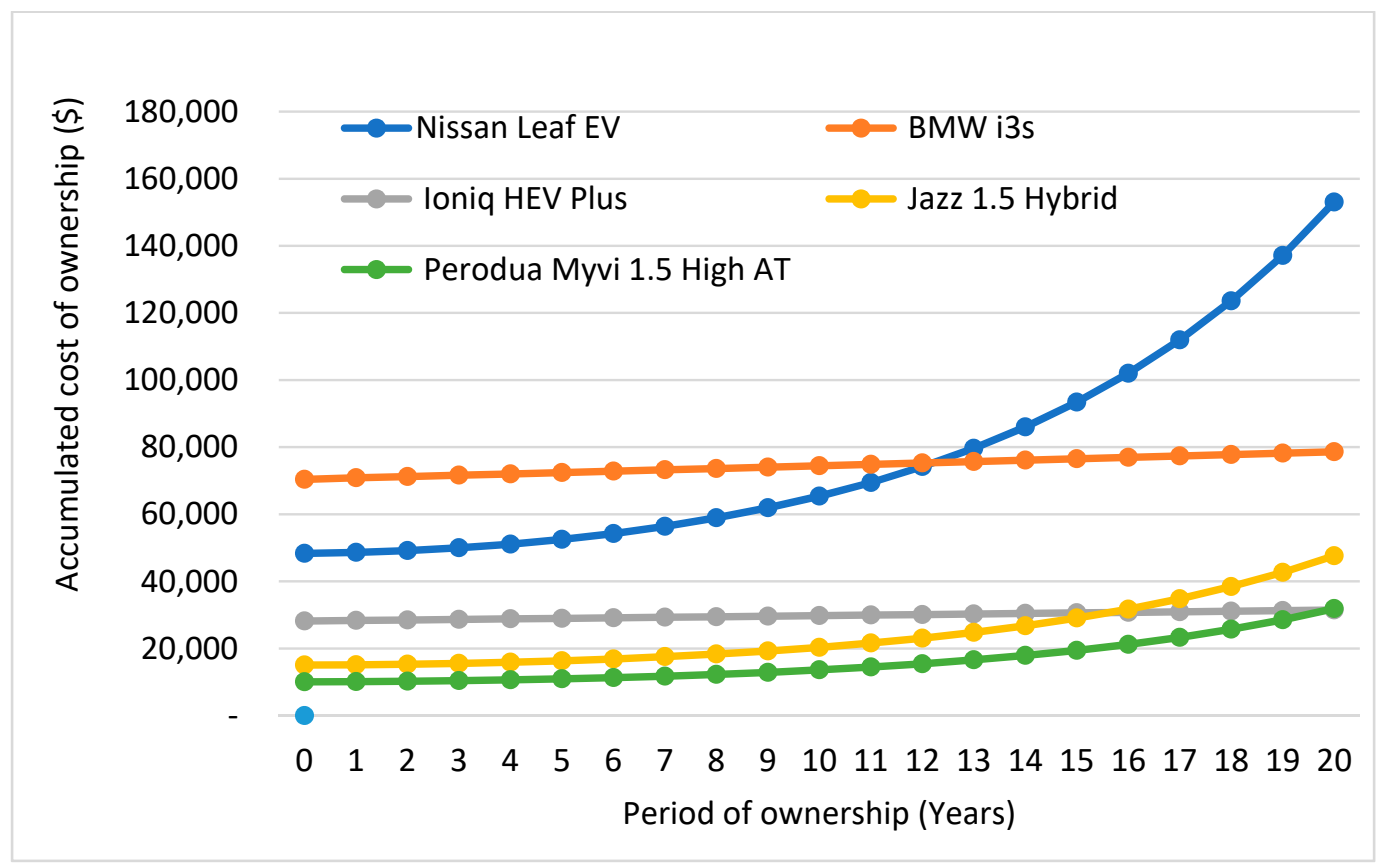

Figure 12. The accumulated cost of ownership for EVs, HEVs, and ICV in Malaysia.

\section{Conclusions and Policy Implications}

In this study, the cost competitiveness of electric vehicles in Malaysia has been investigated in comparison with HEVs and ICV. The cost analysis of the EVs, HEVs, and ICV was performed using the life cycle cost approach employing the prevailing data within the Malaysian context. The detailed analysis revealed that the operating costs significantly influenced the LCC of the EVs, HEVs, and ICV. The operating costs of the EVs were found to be higher compared to that of the HEVs but lower than the Perodua Myvi 1.5 AT which is an ICV. The sensitivity analysis based on the changes in the cost components revealed that the operating costs of the EVs slightly increased during the 
period of ownership. The LCC of the Nissan Leaf and BMW i3s EVs were found to be higher than the HEVs and the Perodua Myvi 1.5 AT which implies that the cost of ownership of EVs in Malaysia is not yet competitive. The accumulated cost of ownership of the two EVs was found to increase based on the changes in the cost components throughout the ownership period. Although EVs sales in Malaysia are limited at the moment, studies have shown that there is a great prospect for EVs market in the future provided the level of awareness for the adoption of EVs is intensified. Besides, necessary policies required to increase the adoption of EVs in Malaysia need to be put in place and the existing one needs to be reviewed from time to time to see the extent and efficiency of implementation. The implementation of the proposed EV components of the 2020 National Automotive Policy needs to be given a serious commitment despite the financial constraints that might arise as a result of the COVID-19 pandemic. Hence, priority must be given to fast-tracking the development of advanced electrode and electrolytes for lithium-ion battery, the development of lithium-ion battery module packaging and testing, development of next-generation battery technology roadmap, and lithium-ion battery material manufacturing scale-up. Besides, appropriate policies that encourage incentives for ownership of EVs in Malaysia should be put in place.

Supplementary Materials: The following are available online at http://www.mdpi.com/2071-1050/12/13/5303/s1.

Author Contributions: All authors have read and agreed to the published version of the manuscript. Conceptualization, S.I.M.; methodology, B.V.A.; software, B.V.A.; Analysis, F.O.A. and B.V.A., validation, B.V.A., and S.I.M.; resources, S.I.M.; data curation, B.V.A. and W.W.M.I.; writing-B.V.A.; writing-review and editing, B.V.A. and S.I.M.; visualization, B.V.A.; supervision, S.I.M.; funding acquisition, S.I.M.

Funding: This research was supported by Universiti Tenaga Nasional with grant number [J510050879].

Acknowledgments: The authors acknowledge the financial support of Universiti Tenaga Nasional.

Conflicts of Interest: The authors declare no conflict of interest.

\section{Abbreviations}

$\begin{array}{ll}\mathrm{BEVs} & \text { Battery Electric Vehicles } \\ \mathrm{CO}_{2} & \text { Carbon dioxide } \\ \mathrm{EVs} & \text { Electric Vehicles } \\ \text { ICVs } & \text { Internal Combustion Engine Vehicles } \\ \mathrm{HEVs} & \text { Hybrid Electric Vehicles } \\ \text { FCEVs } & \text { Fuel Cell Electric Vehicles } \\ \text { FCHEVs } & \text { Fuel Cell Hybrid Electric Vehicles } \\ \text { MSRP } & \text { Manufacturer Sales Recommended Price } \\ \text { LCC } & \text { Life Cycle Cost Analysis }\end{array}$

\section{References}

1. Du, H.; Chen, Z.; Peng, B.; Southworth, F.; Ma, S.; Wang, Y. What drives $\mathrm{CO}_{2}$ emissions from the transport sector? A linkage analysis. Energy 2019, 175, 195-204. [CrossRef]

2. Khalili, S.; Rantanen, E.; Bogdanov, D.; Breyer, C. Global transportation demand development with impacts on the energy demand and greenhouse gas emissions in a climate-constrained world. Energies 2019, 12, 3870. [CrossRef]

3. Keller, V.; Lyseng, B.; Wade, C.; Scholtysik, S.; Fowler, M.; Donald, J.; Palmer-Wilson, K.; Robertson, B.; Wild, P.; Rowe, A. Electricity system and emission impact of direct and indirect electrification of heavy-duty transportation. Energy 2019, 172, 740-751. [CrossRef]

4. Wanitschke, A.; Hoffmann, S. Are battery electric vehicles the future? An uncertainty comparison with hydrogen and combustion engines. Environ. Innov. Soc. Transit. 2019, 1-15. [CrossRef]

5. Ridzuan, A.R.; Albani, A.; Latiff, A.R.A.; Mohamad, M.I; Murshidi, M.H. The impact of energy consumption based on fossil fuel and hydroelectricity generation towards pollution in Malaysia, Indonesia and Thailand. Int. J. Energy Econ. Policy 2020, 10, 215-227. [CrossRef] 
6. Shafie, S.M.; Mahlia, T.M.I.; Masjuki, H.H.; Andriyana, A. Current energy usage and sustainable energy in Malaysia: A review. Renew. Sustain. Energy Rev. 2011, 15, 4370-4377. [CrossRef]

7. Ong, H.C.; Mahlia, T.M.I.; Masjuki, H.H. A review on energy pattern and policy for transportation sector in Malaysia. Renew. Sustain. Energy Rev. 2012, 16, 532-542. [CrossRef]

8. Mustapa, S.I.; Bekhet, H.A. Analysis of $\mathrm{CO}_{2}$ emissions reduction in the Malaysian transportation sector: An optimisation approach. Energy Policy 2016, 89, 171-183. [CrossRef]

9. NAP. National Automotive Policy 2020. Ministry of Internationa Trade and Industry, Malaysia 2020; 1-68. Available online: https://www.miti.gov.my/index.php/pages/view/nap2020 (accessed on 29 June 2020).

10. Iskandar, M.L.; Ariffin, A.S. Relationship between National Automotive Policy (NAP), innovation and automotive vendors' performance in Malaysia. Manag. Sci. Lett. 2019, 9, 1181-1198. [CrossRef]

11. Rahim, N.A.; Che, H.S.; Hasanuzzaman, M.; Habib, A. Toward Cleaner Cities: Renewable Energy Initiatives in Malaysia BT-Devising a Clean Energy Strategy for Asian Cities; Farzaneh, H., Ed.; Springer Singapore: Singapore, 2019; pp. 165-185. [CrossRef]

12. International Energy Agency. Global EV Outlook 2019 launched at Clean Energy Ministerial Read the Report. 2019. Available online: https://www.iea.org/news/global-ev-outlook-2019-launched-at-cleanenergy-ministerial (accessed on 29 June 2020).

13. Oak Ridge National Laboratory. Malaysia $-\mathrm{CO}_{2}$ Emissions. Carbon Dioxide Inf Anal Center, Environ Sci Div Oak Ridge Natl Lab Tennessee, United States 2014. Available online: https:/www.indexmundi.com/ facts/malaysia/co2-emissions (accessed on 18 April 2020).

14. Lieven, T.; Mühlmeier, S.; Henkel, S.; Waller, J.F. Who will buy electric cars? An empirical study in Germany. Transp. Res. Part D Transp. Environ. 2011, 16, 236-243. [CrossRef]

15. Mersky, A.C.; Sprei, F.; Samaras, C.; Qian, Z.S. Effectiveness of incentives on electric vehicle adoption in Norway. Transp. Res. Part D Transp. Environ. 2016, 46, 56-68. [CrossRef]

16. Vergis, S.; Chen, B. Comparison of plug-in electric vehicle adoption in the United States: A state by state approach. Res. Transp. Econ. 2015, 52, 56-64. [CrossRef]

17. Wang, N.; Tang, L.; Pan, H. Effectiveness of policy incentives on electric vehicle acceptance in China: A discrete choice analysis. Transp. Res. Part A Policy Pract. 2017, 105, 210-218. [CrossRef]

18. Diao, Q.; Sun, W.; Yuan, X.; Li, L.; Zheng, Z. Life-cycle private-cost-based competitiveness analysis of electric vehicles in China considering the intangible cost of traffic policies. Appl. Energy 2016, 178, 567-578. [CrossRef]

19. Kara, S.; Li, W.; Sadjiva, N. Life Cycle Cost Analysis of Electrical Vehicles in Australia. Procedia CIRP 2017, 61, 767-772. [CrossRef]

20. Adnan, N.; Nordin, S.M.; Rahman, I. Adoption of PHEV/EV in Malaysia: A critical review on predicting consumer behaviour. Renew. Sustain. Energy Rev. 2017, 72, 849-862. [CrossRef]

21. Adnan, N.; Nordin, S.M.; Rahman, I.; Rasli, A.M. A new era of sustainable transport: An experimental examination on forecasting adoption behavior of EVs among Malaysian consumer. Transp. Res. Part A Policy Pract. 2017, 103, 279-295. [CrossRef]

22. Islam, M.M.; Shareef, H.; Mohamed, A. Optimal siting and sizing of rapid charging station for electric vehicles considering Bangi city road network in Malaysia. Turk. J. Electr. Eng. Comput. Sci. 2016, 24, 3933-3948. [CrossRef]

23. Salehen, P.M.W.; Su'Ait, M.S.; Razali, H.; Sopian, K. Battery management systems (BMS) optimization for electric vehicles (EVs) in Malaysia. AIP Conf. Proc. 2017, 1831, 1-8. [CrossRef]

24. Sang, Y.N.; Bekhet, H.A. Modelling electric vehicle usage intentions: An empirical study in Malaysia. J. Clean. Prod. 2015, 92, 75-83. [CrossRef]

25. Ayodele, B.V.; Mustapa, S.I. Life Cycle Cost Assessment of Electric Vehicles: A Review and Bibliometric Analysis. Sustainability 2020, 12, 2387. [CrossRef]

26. Mytilinou, V.; Kolios, A.J. Techno-economic optimisation of offshore wind farms based on life cycle cost analysis on the UK. Renew. Energy 2019, 132, 439-454. [CrossRef]

27. Delucchi, M.A.; Lipman, T.E. An analysis of the retail and lifecycle cost of battery-powered electric vehicles. Transp. Res. Part D Transp. Environ. 2001, 6, 371-404. [CrossRef]

28. Ogden, J.M.; Williams, R.H.; Larson, E.D. Societal lifecycle costs of cars with alternative fuels/engines. Energy Policy 2004, 32, 7-27. [CrossRef] 
29. Lipman, T.E.; Delucchi, M.A. A retail and lifecycle cost analysis of hybrid electric vehicles. Transp. Res. Part D Transp. Environ. 2006, 11, 115-132. [CrossRef]

30. Offer, G.J.; Howey, D.; Contestabile, M.; Clague, R.; Brandon, N.P. Comparative analysis of battery electric, hydrogen fuel cell and hybrid vehicles in a future sustainable road transport system. Energy Policy 2010, 38, 24-29. [CrossRef]

31. Sharma, R.; Manzie, C.; Bessede, M.; Brear, M.J.; Crawford, R.H. Conventional, hybrid and electric vehicles for Australian driving conditions - Part 1: Technical and financial analysis. Transp. Res. Part C Emerg. Technol. 2012, 25, 238-249. [CrossRef]

32. CarBase. Hybrid and EV Cars in Malaysia-Reviews, Specs, Prices. Driven Technol Sdn Bhd All 2020:1-13. Available online: https://www.carbase.my/body-type/hybrid-and-ev (accessed on 18 April 2020).

33. Hawkins, T.R.; Singh, B.; Majeau-Bettez, G.; Strømman, A.H. Comparative Environmental Life Cycle Assessment of Conventional and Electric Vehicles. J. Ind. Ecol. 2013, 17, 53-64. [CrossRef]

34. Girardi, P.; Gargiulo, A.; Brambilla, P.C. A comparative LCA of an electric vehicle and an internal combustion engine vehicle using the appropriate power mix: The Italian case study. Int. J. Life Cycle Assess. 2015, 20 , 1127-1142. [CrossRef]

35. Coren, M.J. The Median Electric Car in the US is Getting Cheaper. Quartz 2019:1-7. Available online: https: //qz.com/1695602/the-average-electric-vehicle-is-getting-cheaper-in-the-us/ (accessed on 18 April 2020).

36. Gent, E. Electric Cars Are Estimatedto Be Cheaper than Regular Cars by 2022. Singularityhyb 2020:1-9. Available online: https://singularityhub.com/2019/04/29/electric-cars-are-estimated-to-be-cheaper-thanregular-cars-by-2022/ (accessed on 18 April 2020).

37. AECOM. Economic Viability of Electric Vehicles. Sydney: 2009. 1-84. Available online: https://www. environment.nsw.gov.au/resources/climatechange/ElectricVehiclesReport.pdf (accessed on 18 April 2020).

38. Bakker, D. Battery Electric Vehicles: Performance, $\mathrm{CO}_{2}$ Emissions, Lifecycle Costs and Advanced Battery Technology Development; University of Utrcht: Utrecht, The Netherlands, 2010.

39. EPRI. Total Cost of Ownership Model for Current Plug-in Electric Vehicles; EPRI: Palo Alto, CA, USA, 2013.

40. Hidrue, M.K.; Parsons, G.R.; Kempton, W.; Gardner, M.P. Willingness to pay for electric vehicles and their attributes. Resour. Energy Econ. 2011, 33, 686-705. [CrossRef]

41. Eddie. The Contradictions of Malaysia's Electric Car Policy. IBR Asia Gr 2020:10-22. Available online: https: //www.ibrasiagroup.com/the-contradictions-of-malaysias-electric-car-policy/ (accessed on 18 April 2020).

(C) 2020 by the authors. Licensee MDPI, Basel, Switzerland. This article is an open access article distributed under the terms and conditions of the Creative Commons Attribution (CC BY) license (http://creativecommons.org/licenses/by/4.0/). 